Eur J Clin Chem Clin Biochem

1995; 33:791-797

(ㄷ) 1995 Walter de Gruyter \& Co. Berlin - New York

\title{
Non-Transferrin Iron Uptake by HeLa Cells Cultured in Serum-Free Media with Different Iron Sources ${ }^{1}$ )
}

\author{
By Karin Kriegerbecková, Lise Döpper, Barbara Scheiber, Jan Kovár and Hans Goldenberg \\ Institut für Medizinische Chemie der Universität Wien, Wien, Austria
}

(Received May 8, 1995)

Dedicated to Prof. Dr. Erich Kaiser on the occasion of his 70th birthday

\begin{abstract}
Summary: HeLa cells cultured in defined serum-free media supplied with iron either in the form of diferric transferrin (transferrin-dependent cells), ferric citrate at $500 \mu \mathrm{mol} / 1$ (high-iron dependent cells) or ferric citrate at $5 \mu \mathrm{mol} / \mathrm{l}$ (low-iron dependent cells) accumulate iron from ferric citrate in different ways. The uptake rate in transferrin-dependent cells is always much lower than in the other two lines. In all three, the uptake rate rises almost linearly with the concentration of iron up to $10 \mu \mathrm{mol} / 1$. In high-iron dependent cells, the uptake of radiolabelled iron is suppressed by a 100-fold excess of the iron complex, whereas this same excess stimulates iron uptake in the other two lines. The same concentrations of pure citrate completely inhibit iron uptake by all three types of cell. Only high-iron dependent cells take up citrate at measurable and reproducible rates. These rates are independent of the presence of iron, and the uptake is inhibited by an unlabelled surplus. The $\mathrm{pH}$-dependence of iron uptake in high-iron dependent cells is also different from that of the other cells.
\end{abstract}

Low-iron dependent cells transferred to medium containing $500 \mu \mathrm{mol} / 1$ iron show increased uptake rates within 3 to $7 \mathrm{~h}$, and after overnight maintenance in this medium they acquire the uptake characteristics of high-iron dependent cells.

The special characteristics of iron uptake by high-iron dependent cells are paralleled by low binding activity of iron-regulatory protein to iron-responsive elements of RNA.

We conclude that low-iron dependent cells maintain their iron supply from the culture medium by unspecific uptake of oligomeric complexes, while cells in media with a high content of low-molecular weight iron induce a specific uptake system which might have a protective function.

\section{Introduction}

Iron is absolutely essential for life. In particular, proliferating cells have high requirements for iron because of its critical role as a cofactor of ribonucleoside diphosphate reductase $(1,2)$. Mammalian cells acquire iron mainly from the transport glycoprotein transferrin, for which cells in need express a specific receptor. Transfer-

\footnotetext{
1) This work was supported by the "Fonds zur Förderung der Wis-
} senschaftlichen Forschung in Österreich", Proj. \# P-9261Med rin binds to this receptor, is endocytosed and the iron is released in the endocytic compartment subsequent to acidification by a proton ATPase (3). The mechanism of further transport of the metal into the cytosol is largely unknown.

One of the functions of transferrin is to avoid toxic effects of iron bound to low molecular mass anions where it can initiate lipid peroxidation in the plasma (4). Iron bound to transferrin has a very low oxidation potential and is thus not toxic (5). 
On the other hand, serum-free tissue culture (6) has been used to study some cellular functions, in particular the secretion of proteins such as antibodies (7). Moreover, cells and tissues come into contact with non-transferrin iron in pathological situations, such as iron overload or destruction of cells. They must therefore avoid the toxic effects of this free iron, and the most appropriate strategy would be to render it harmless by incorporation into the intracellular storage protein ferritin. This requires uptake by non-transferrin dependent mechanisms, a process generally termed non transferrin-bound iron uptake, which has recently gained interest amongst investigators studying iron metabolism (8-16). It has been found that the uptake capacity of some cultured cells rises when they come in contact with high concentrations of free iron $(10,15$, 17). Knowledge of these transport mechanisms might lead to improved methods for treatment of iron overload conditions with appropriate chelators.

Certain human tumour cell lines are suitable for study because they have a steady iron requirement (see above), but not every one can be adapted to proliferate in protein-free media at very low iron concentrations $(5 \mu \mathrm{mol} / \mathrm{l}$ or below) (18). In fact, these cells proliferate in so-called iron-free media, which always contain small amounts of iron as a contaminant of the chemicals used to make them. The usual protein-free media $(6,18,19)$, however, contain a hundredfold concentration of iron, usually in the form of iron citrate, which represents a relatively high concentration of freely available iron, but can on the other hand be quite toxic. Though $5 \mu \mathrm{mol} / 1$ iron is still above the concentration of transferrin iron needed to saturate the transferrin receptors $(200 \mathrm{nmol} / \mathrm{l})$, it is below the physiological concentration of transferrin iron (ca. $30 \mu \mathrm{mol} / \mathrm{l}$ ) (20). Indeed, the HeLa cells, whose iron uptake properties are studied in this paper, can be maintained in a serum-free medium at a transferrin concentration of $5 \mathrm{mg} / \mathrm{l}$, corresponding to $130 \mathrm{nmol} / \mathrm{l}$ iron. The high affinity necessary to make iron sufficiently available to the cells is that of the receptor.

Serum-free culture is useful for cells producing endogenous proteins (e.g., antibodies or cytokines) in culture, and low iron might be beneficial for the long-term wellbeing of the cells.

It was our aim to find out whether the HeLa cells proliferating on $5 \mu \mathrm{mol} / 1$ iron ("low-iron dependent cells") have a membrane transport system distinguishable from that of cells proliferating in transferrin-containing medium ("transferrin-dependent cells"), and from those cultured in the medium containing $500 \mu \mathrm{mol} / 1$ iron ("high-iron dependent cells"). It was found that none of these sublines has a high-affinity transport system for non transferrin-bound iron, but there were significant quantitative and qualitative differences in rates, specific- ity, $\mathrm{pH}$-dependence and, interestingly, in the uptake of the accompanying citrate. We also demonstrated a change in the characteristics of iron uptake when the extracellular iron concentration was changed.

\section{Materials and Methods}

$\cdot 1$

\section{Cells and media}

HeLa sublines were cultured from the parent line, a suspensiongrowing variant of HeLa epithelial cells, by adaptation to proteinfree RPMI 1640 medium containing $2 \mathrm{mmol} / 1$ glutamine, 100 $\times 10^{3} \mathrm{U} / 1$ penicillin $/ 100 \mathrm{mg} / 1$ streptomycin and a supply of ions, antioxidants, vitamins and hormones as described in 1.c. (18). Iron was supplied either as transferrin $(5 \mathrm{mg} / \mathrm{l})$, as high iron citrate (500 $\mu \mathrm{mol} / \mathrm{l}$ iron with $750 \mu \mathrm{mol} / \mathrm{l}$ citrate) or as low iron citrate (one hundredth of the high iron, i.e. $5 \mu \mathrm{mol} / /$ iron with $7.5 \mu \mathrm{mol} / / \mathrm{ci}$ trate). The iron-citrate complexes were prepared by mixing a stock of $200 \mathrm{mmol} / \mathrm{l}$ iron chloride in $300 \mathrm{mmol} / 1$ trisodium citrate in water. This mixture was then either freshly diluted with the basic medium 1:400 to yield the high-iron medium before addition to the culture flasks or diluted 1:100 with water and then diluted $1: 400$ to yield the low-iron medium. All additions were sterilefiltered through Corning $0.2 \mu \mathrm{m}$ syringe filters directly into the medium. No special care was taken to prevent hydrolysis and polymerisation in the culture. The fact that the cells were able to proliferate was taken as a sign that they can acquire iron from the source provided.

The cells were kept in the logarithmic growth phase by appropriate dilution twice or three times a week. To change culture conditions for short periods, low-iron dependent cells were transferred to high-iron medium without further treatment.

Harvest of cells and preparation for uptake experiments

The cells were centrifuged in $50 \mathrm{ml}$ tubes at $1200 \mathrm{~min}^{-1}$ for $8 \mathrm{~min}$ in an Eppendorf 5403 tabletop centrifuge. They were washed twice in iron-free culture medium, and re-washed after transfer to new tubes. All these steps were carried out at $37^{\circ} \mathrm{C}$. To remove labile iron, the cells were then incubated in iron-free medium containing $10 \mathrm{~g} / \mathrm{l}$ bovine serum albumin for $30 \mathrm{~min}$ at $37^{\circ} \mathrm{C}$, cooled to $4{ }^{\circ} \mathrm{C}$, centrifuged in the cold and washed with a large volume of icecold medium. They were then counted in a Sysmex cell counter, suspended at a concentration of 3 to $5 \times 10^{9} / 1$ in this medium, the viability (always above $95 \%$ ) checked by staining with Trypan blue, and $7 \mathrm{ml}$ aliquots distributed into small $(25 \mathrm{ml})$ culture flasks.

\section{Uptake}

The cells were preincubated at $37^{\circ} \mathrm{C}$ for $10 \mathrm{~min}$ in a shaking water bath. Then the radioactive sample (iron or citrate) was added. Starting from the zero time point, duplicate samples of $500 \mu \mathrm{l}$ were drawn every five minutes. After ascertaining that uptake was linear for $20 \mathrm{~min}$, this was used as the total time. The withdrawn aliquots were mixed in cooled Eppendorf tubes with equal volumes of icecold medium containing $50 \mu \mathrm{mol} / 1$ diethylene triamine pentaacetate (DTPA) to scavenge all free iron, and the cells were centrifuged through an oil layer of dibutylphthalate and dioctylphthalate (80 +20 , by vol.) as above. The supernatant and the oil were removed by aspiration, the tip of the tube was cut into a scintillation vial and the pellet lysed with $500 \mu \mathrm{l}$ of $0.5 \mathrm{~mol} / \mathrm{K} \mathrm{KOH}$ containing 20 $\mathrm{ml} / 1$ Triton X-100. Lysis was allowed to proceed for $2 \mathrm{~h}$ at $70^{\circ} \mathrm{C}$, the samples were neutralised with $250 \mu \mathrm{l}$ of $1 \mathrm{~mol} / \mathrm{h} \mathrm{HCl}, 4 \mathrm{ml}$ of Beckman Readysafe scintillation fluid was added, and the radioactivity was counted in a Packard LSC counter. Appropriate blanks were performed to correct for radioactivity adhering to the tubes (practically none). Corrections were also made for quenching. 


\section{Release of iron}

The cells were treated in the same way as for uptake, and they were loaded with $500 \mu \mathrm{mol} / 1$ iron containing $5 \mu \mathrm{mol} / 1$ labelled iron as a tracer for 2 hours. The remaining iron was washed away, and the washing efficiency was controlled by scintillation counting. The loaded cells were then re-incubated in the medium at $37^{\circ} \mathrm{C}$. either without iron, with $1 \mathrm{mmol} / 1$ iron-citrate or with $1.5 \mathrm{mmol} / \mathrm{l}$ citrate present. As in the uptake experiments, aliquots were drawn and the iron content of the cells was counted.

\section{Iron complexes}

Complexes for uptake were prepared by diluting either ${ }^{55} \mathrm{FeCl}_{3}$ or non-radioactive iron chloride into an 1.5 fold surplus of trisodium citrate (see preparation of media), or non-radioactive iron chloride into ${ }^{14} \mathrm{C}$-citrate. For uptake of citrate alone, iron was omitted. The freshly prepared iron complex was then used for the uptake experiments.

\section{Iron-regulatory protein assay}

The cells were extracted with lysis buffer $(10 \mathrm{mmol} / \mathrm{l}$ Hepes, $3 \mathrm{mmol} / 1 \mathrm{MgCl}_{2}, 40 \mathrm{mmol} / 1 \mathrm{KCl}, 50 \mathrm{ml} / \mathrm{l}$ glycerol, $1 \mathrm{mmol} / 1$ dithiothreitol, $\mathrm{pH} 7.6(21)$ ), the lysate was freed of debris and nuclei in an Eppendorf centrifuge for $3 \mathrm{~min}$ at $15000 \mathrm{~min}^{-1}$ and the supernatant frozen in fresh tubes at $25 \mu \mathrm{V} / 10^{6}$ cells at $-80^{\circ} \mathrm{C}$ until use. Band-shift assays were carried out by polyacrylamide electrophoresis of RNA-probes as described (22).

\section{Materials}

RPMI medium ( $\mathrm{HCO}_{3}^{-}$-buffered) was obtained from Seromed, glutamine and penicillin-streptomycin from PAA (Linz, Austria). The radiochemicals were from NEN: iron-55 chloride, specific activity of $182 \mathrm{TBq} / \mathrm{mol} ;\left[{ }^{14} \mathrm{C}\right]$ citrate, specific activity of $3.1 \mathrm{TBq} / \mathrm{mol}$. Diferric transferrin was obtained from Boehringer-Mannheim, dibutylphthalate from Serva, dioctylphthalate from Aldrich.

\section{Results and Discussion}

The three sublines of HeLa obtained by culturing with different iron sources differed in their initial rate of iron uptake from the iron-citrate complex. The uptake rate was linear with time for at least $20 \mathrm{~min}$ in all cases. The highest rates were always observed with high-iron dependent cells, i. e. those maintained with the highest concentration of free iron. However, on averaging a number of experiments ( 10 in the case of high-iron dependent and low-iron dependent, 9 in the case of transferrin-dependent cells), the difference in initial uptake rate was not significant between the two lines grown with non-transferrin-iron: The rates were 620 $\pm 150 \mathrm{fmol} / \mathrm{min} \cdot 10^{6}$ cells (corresponding to $6200 \mathrm{Fe}$ atoms/s $\cdot$ cell) for high-iron dependent cells, $560 \pm 163$ for low-iron dependent cells, and $200 \pm 70$ $\mathrm{fmol} / \mathrm{min} \cdot 10^{6}$ cells for transferrin-dependent cells, which had significantly lower uptake rates. At a first glance, these differences are not unexpected. It has been shown in several instances that free (i. e. non-transferrin) iron in the environment induces an increase in the cellular uptake capacity for non transferrin-bound iron (10,
$15,17)$. This does not, however, correspond to the level of "free" intracellular iron, which is reflected by the IRE (iron-responsive element)-binding activity of the ironregulatory protein $(22,23)$. Band-shift assays with labelled hairpin-elements of iron-responsive mRNA showed that high-iron dependent cells had very low binding activity, which means high intracellular iron concentration. The transferrin-dependent-line showed high RNA-binding activity, while the low-iron dependent cells showed intermediate RNA-binding activity. After overnight incubation of the cells in iron-free medium, low-iron dependent cells behaved like transferrindependent cells (both showed increased IRE-binding capacity), while the high-iron dependent cells remained unchanged. No desferroxamine was needed to bring about these changes in the low-iron dependentand the transferrin-dependent cells. The regulatory iron stores of the high-iron dependent cells were apparently high enough to keep iron-regulatory protein in the non-binding form even without a steady supply of iron (fig. 1).

Three criteria were found which distinguished non transferrin-bound iron uptake in high-iron dependent and in low-iron dependent cells and showed qualitative similarities between transferrin-dependent and low-iron dependent cells: specificity, uptake of citrate and pH-dependence.

The first was the specificity of the uptake process as demonstrated by the ability of a surplus of iron-citrate complex to inhibit uptake of radioactive iron. Inhibition, which was, however, only partial, was only seen with

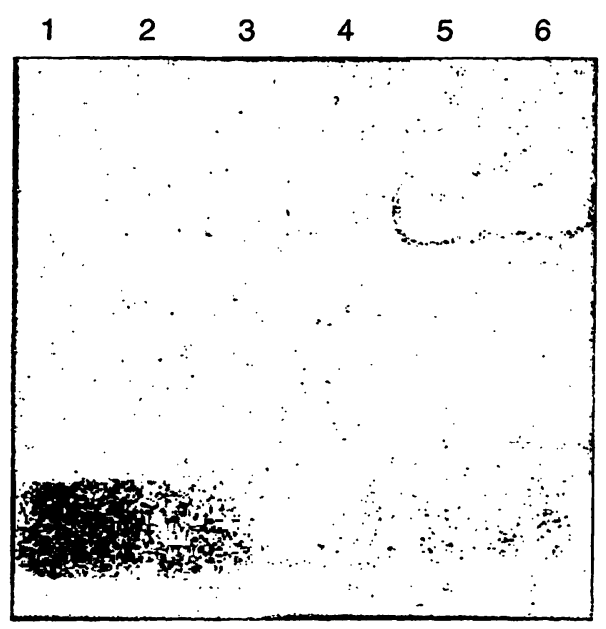

Fig. 1 Band-shift assay of iron-regulatory protein with a ${ }^{32} \mathrm{P}-\mathrm{la}-$ belled mRNA probe containing an iron-responsive element (22).

Lanes 1 and 4: High-iron dependent cells,

2 and 5: Low-iron dependent cells,

3 and 6: Transferrin-dependent cells.

Lanes 1, 2, 3: extracts from cells in their native medium,

4, 5, 6: extracts made after overnight incubation of the cells in iron-free medium.

The unbound RNA is the strong band in the lower part of the radiograph. 

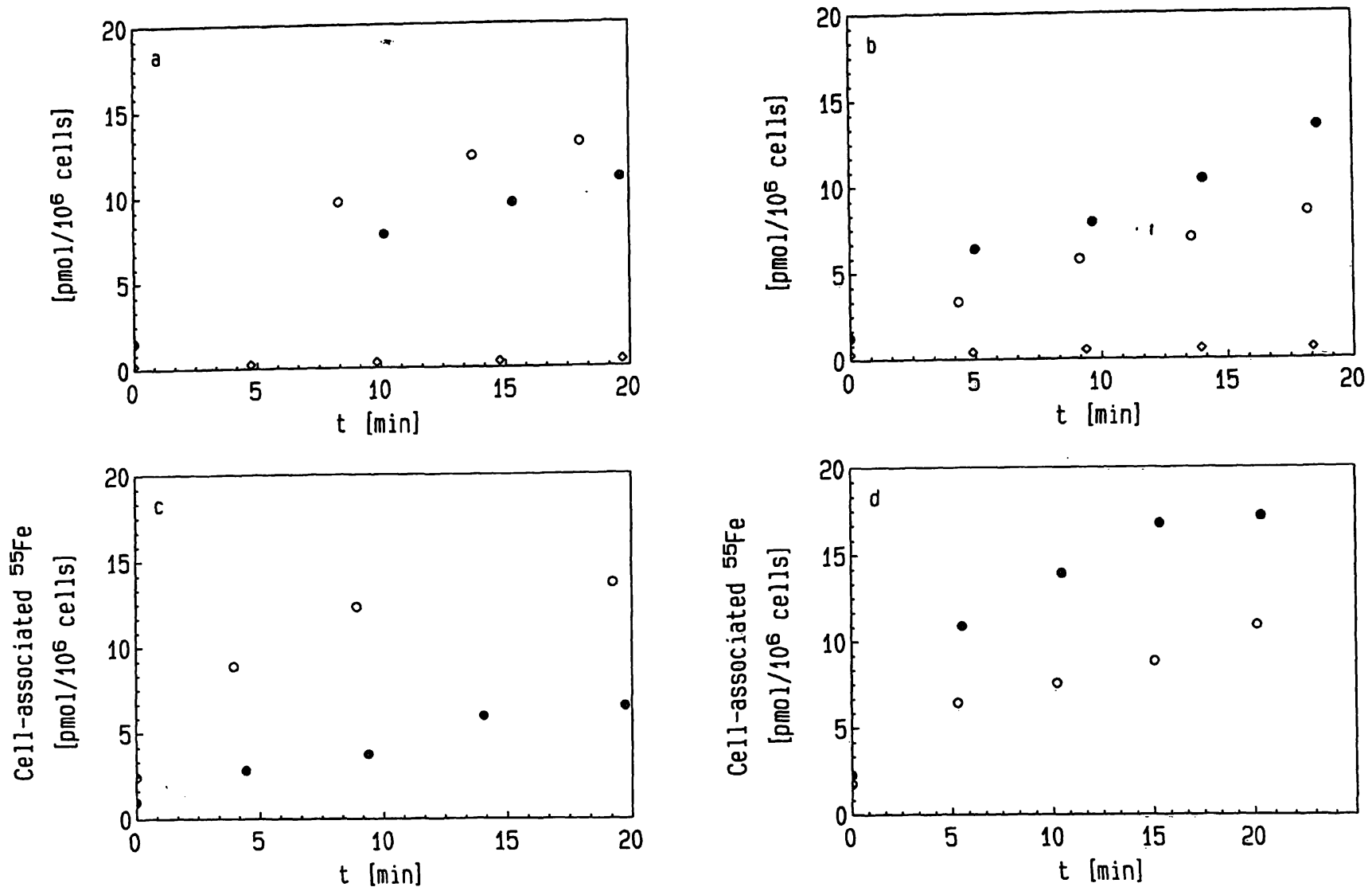

Fig. 2 Uptake of iron by the different HeLa cell subtypes. The cells were incubated in RPMI-medium with $0.25 \mu \mathrm{mol} / 1$ 年 $\mathrm{Fe}$-citrate $(0.375 \mu \mathrm{mol} / \mathrm{l}$ citrate) and aliquots withdrawn at indicated times $(0)$. To investigate specificity, the cells were incubated with $25 \mu \mathrm{mol} / \mathrm{l}$ unlabelled Fe-citrate (O) or with $37.5 \mu \mathrm{mol} / /$ pure citrate $(\diamond)$.

a) Low-iron dependent cells;

b) High-iron dependent cells;

high-iron dependent cells. In the other two lines, a hundredfold surplus of iron-citrate unexpectedly stimulated the uptake of labelled iron (fig. 2). One explanation would be the stimulation of an exchange carrier by the external iron. This was excluded by the results of release experiments. The rate of release of iron from cells to the extracellular medium was independent of the presence of iron in this medium, and was too slow to account for the stimulation observed (fig. 3). Rather, one might expect that the uptake itself reflects phagocytosis of polynucleated complexes, the formation of which might be enhanced with higher concentrations. Thus, the species crossing into the cells may be oligomeric iron complexes. This hypothesis is strenghened by the fact that a surplus of citrate alone totally inhibited iron uptake from this source (fig. 2). Citrate in sufficient concentration prevents polynucleation of iron $(11,24)$. The inhibition by surplus Fecitrate observed in high-iron dependent cells, on the other hand, indicates that in this case the uptake of iron was at least partly due to a specific process.

The dependence of the rate on the concentration of iron clearly showed the absence of any high-affinity transport

c) Transferrin-dependent cells;

d) low-iron dependent cells

kept overnight in high-iron medium containing $500 \mu \mathrm{mol} / \mathrm{l}$ iron (instead of $5 \mu \mathrm{mol} / /$ in low-iron medium).

One typical experiment out of a series of 9 to 10 (see text) is shown.

moiety in each of the three cell lines up to a concentra-

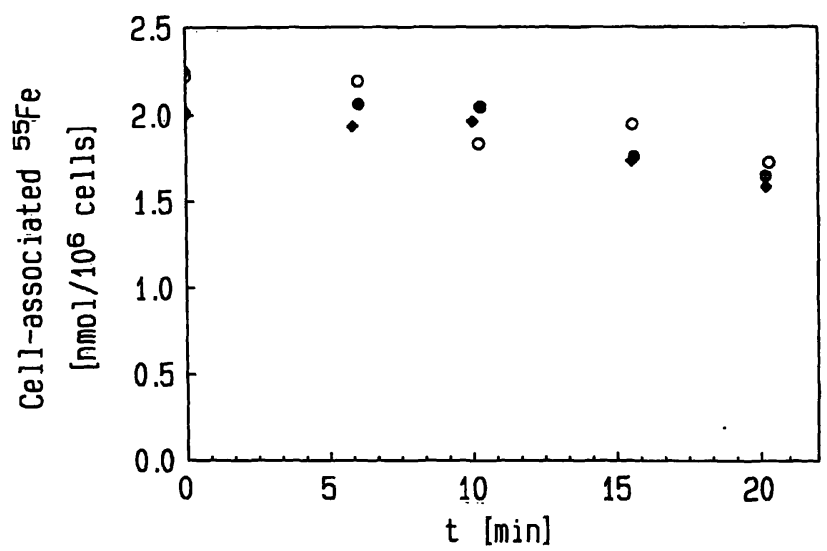

Fig. 3 Release of iron from cells preloaded with Fe-citrate for $2 \mathrm{~h}$ at $37^{\circ} \mathrm{C}$. Preloading was carried out with $500 \mu \mathrm{mol} / /$ iron with $5 \mu \mathrm{mol} / 1{ }^{55} \mathrm{Fe}$ as a tracer. After removing the extracellular iron and washing the cells, they were re-incubated in RPMI-medium for the indicated times. Then aliquots were removed and the cellular iron content counted. The data shown are the total iron calculated from the tracer concentration. Release was measured either in the presence of pure medium $(\bullet)$, medium with $1 \mathrm{mmol} / \mathrm{he}$-citrate (O). or with $1.5 \mathrm{mmol} / \mathrm{l}$ citrate alone $(\diamond)$.

The data show one representative experiment. 

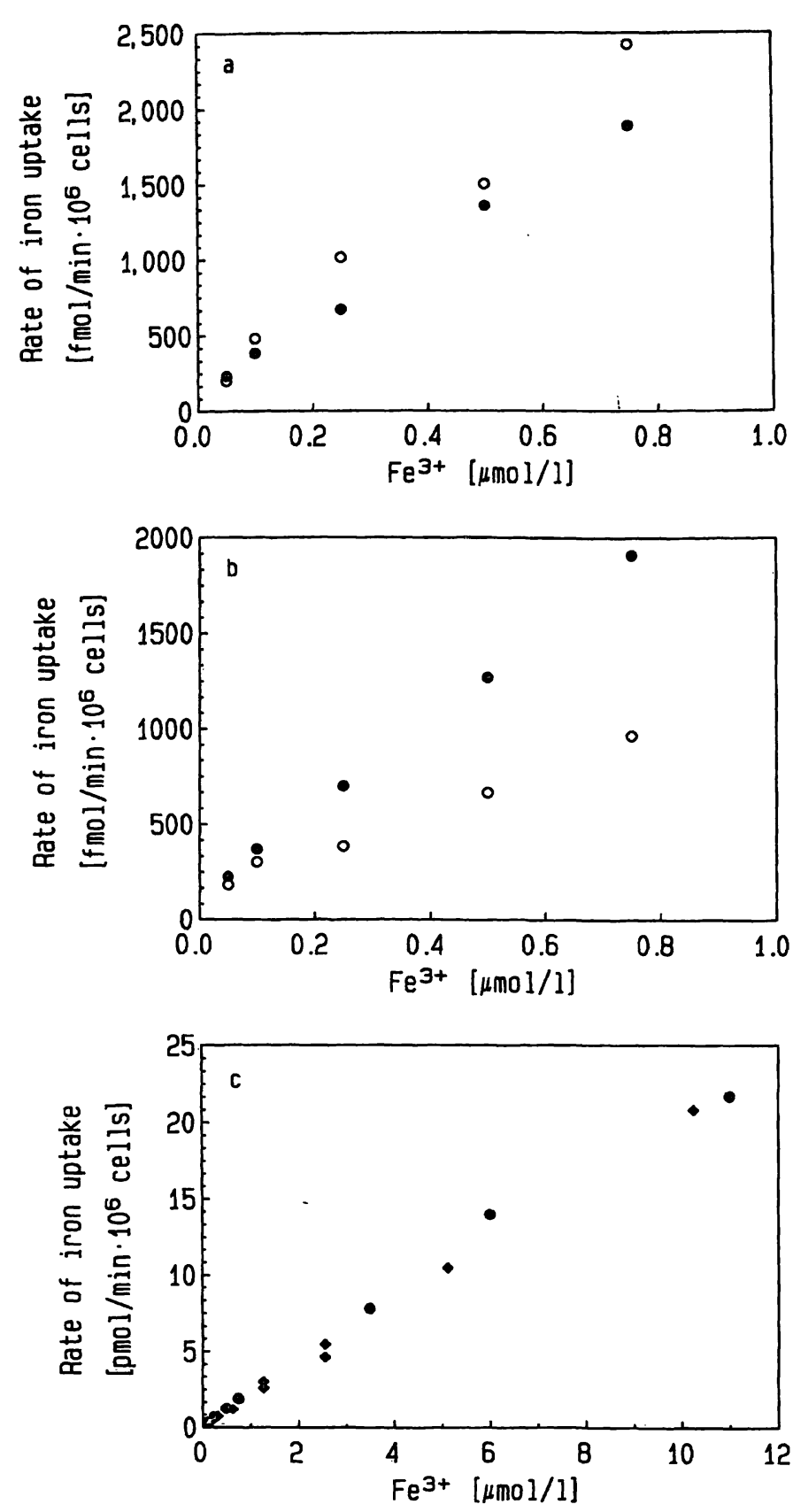

Fig. 4 Dependence of the rate of iron uptake by HeLa cells on the concentration of iron in the absence $(0)$ or in the presence $(0)$ of unlabelled Fe-citrate (100-fold-concentration).

a) Low-iron dependent cells, low concentration range;

b) High-iron dependent cells, low concentration range;

c) low-iron dependent $-(\diamond)$ and high-iron dependent $-(\bullet)$ cells, high concentration range.

The data are combined from 4 experiments.

tion of $10 \mu \mathrm{mol} / 1$ (fig. 4c). The characteristics of the "hot + cold" experiments, i.e. stimulation in low-iron dependent, inhibition in high-iron dependent cells, remained unchanged over the concentration range tested (fig. 4a, b). The kinetics of the transferrin-dependent-line are not shown, but they show the same pattern as the low-iron dependent-line, only with lower rates.

The uptake of citrate might provide a clue to the mechanisms involved in the iron uptake, in particular whether the complex could be internalised as such. Only in high- iron dependent cells was there a measurable uptake of citrate, irrespective of whether citrate was part of the iron-citrate complex or was supplied to the cells as pure salt. This uptake rate was about $130 \mathrm{fmol} / \mathrm{min} \cdot 10^{6}$ cells, considerably lower than the rate of iron uptake. A similar finding has been reported for fibroblasts (25). A surplus of unlabelled citrate totally inhibited the uptake, indicating that it used a specific transport system (fig. 5a). Higher uptake of citrate is not surprising for cells with low IRE-binding activity, because the iron-replete iron-regulatory protein acts as an aconitase (26) and may provide a concentration gradient for a carrier-mediated uptake. Though we did not measure aconitase activity, the relation has been quite firmly established and explains our findings.

When the $\mathrm{pH}$ was changed, there were also changes in the iron uptake rate. For comparison, the relative rates are shown in the figure, with the highest rate observable arbitrarily taken as $100 \%$; this occurred at $\mathrm{pH} 5$ for lowiron dependent, and $\mathrm{pH} 5.5$ for the other two cells. But the real difference was revealed at physiological $\mathrm{pH}$, when the high-iron dependent cells remained at high rates, while the other two showed lower rates (fig. 6). It is clear, that the concentration of freely available iron increases with lower $\mathrm{pH}$ (24), but this seemed to be more important for the cells in the low-iron state, lowiron dependent and transferrin-dependent. In the absence of information on transport molecules we have no explanation for this, but it shows the difference between the behaviour of cells suspended in low or in high iron medium. HeLa-cells grown in ordinary serum-containing medium and incubated with high concentrations of ferric ammonium citrate overnight have higher rates of non transferrin-bound iron uptake (10). Low-iron dependent cells reacted more rapidly when transferred to the highiron medium. An increase in the uptake rate was observed early at three hours after transfer, and after seven hours the rate nearly tripled (fig. 7). It was thus considerably higher than in ordinary high-iron dependent cells. That could mean that the cells display an ironstress response when threatened by high concentrations of the metal, but return to normal rates once they are accustomed to this environment. The reason for this could be enhanced synthesis of ferritin, triggered by inactivation of the iron-regulatory protein (23). Indeed, after an overnight incubation, the rate was in the usual range (between 700 and $900 \mathrm{fmol} / \mathrm{min} \cdot 10^{6}$ cells in three experiments), but the properties had now completely changed to those found in the high-iron dependent-line; thus surplus of iron-citrate inhibited (fig. 2d), there was uptake of citrate (fig. 5b), and this was the same in the presence and in the absence of iron. It seems that certain cells can obtain iron from any source of low concentration by an unspecific transport mechanism. The fact that 


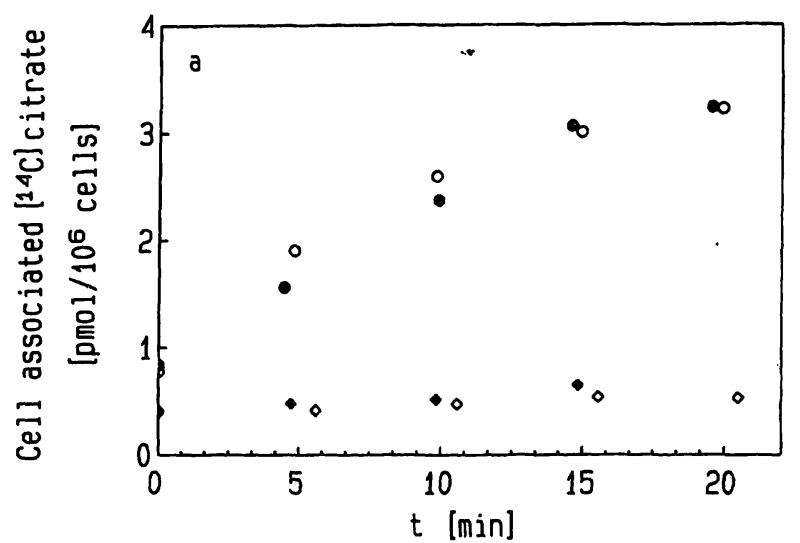

Fig. 5 Uptake of $\left[{ }^{14} \mathrm{C}\right]$ citrate by high-iron dependent cells (a) and by low-iron dependent cells incubated in $500 \mu \mathrm{mol} / \mathrm{l} \mathrm{Fe}$-citrate overnight (see fig. 2d) (b).

The uptake experiments were carried out exactly as in figure 2. The cells were incubated either with $0.25 \mu \mathrm{mol} / \mathrm{Fe}-\left[{ }^{14} \mathrm{C}\right]$ citrate

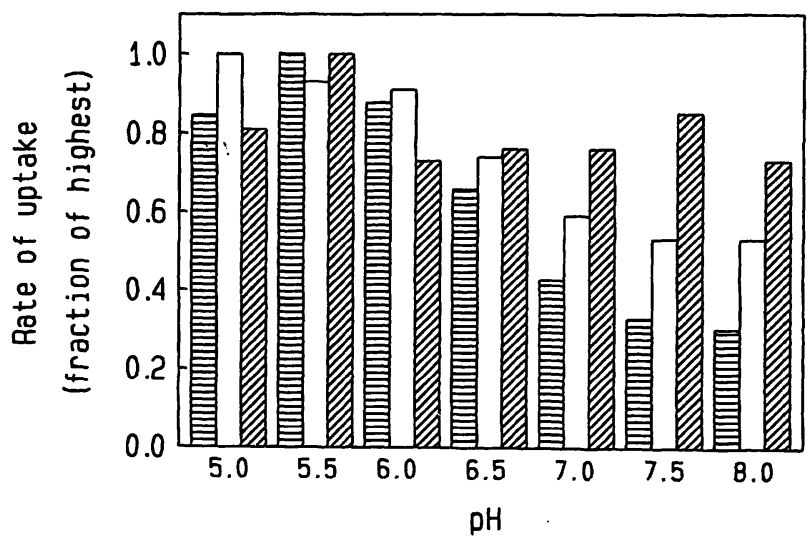

Fig. 6 Dependence of the rate of iron uptake of low-iron dependent cells (open bars), high-iron dependent cells (diagonally shaded bars) and transferrin-dependent cells (horizontally shaded bars) on $\mathrm{pH}$.

The data are the means of two experiments. To make the rates comparable, the respective highest was set 1.0.

this property is confined to certain cell lines, found experimentally by chance may indicate that this is not a general property (7). Usually mammalian cells acquire iron from transferrin via endocytosis. Though this also requires the presence of some transport system in the endosomal membrane, it is probably different from the one observed in this study because it must be ubiquitous. This, however, is speculation, and experiments to clarify this question are in progress.

On the other hand, in the presence of high iron concentrations in the environment, and especially under conditions where the iron is rapidly increased, the cells adapt by expressing a specific transport. This may be due to regulation on the level of mRNA, in the sense of the

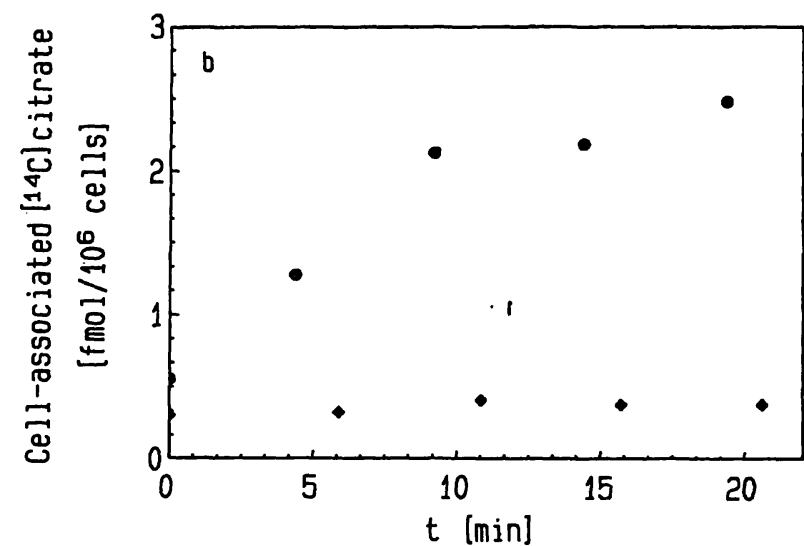

$(1: 1.5)(0)$ or with $0.375 \mu \mathrm{mol} / 1\left[{ }^{14} \mathrm{C}\right]$ citrate alone (0), and in the absence and the presence of $3.75 \mathrm{mmol} / \mathrm{l}$ unlabelled citrate $(\diamond, \diamond)$. One representative experiment is shown. In case of low-iron dependent cells (b), the uptake of citrate alone is not shown, but also occurred with practically the same rate as that of $\mathrm{Fe}-\left[{ }^{14} \mathrm{C}\right]$ citrate.

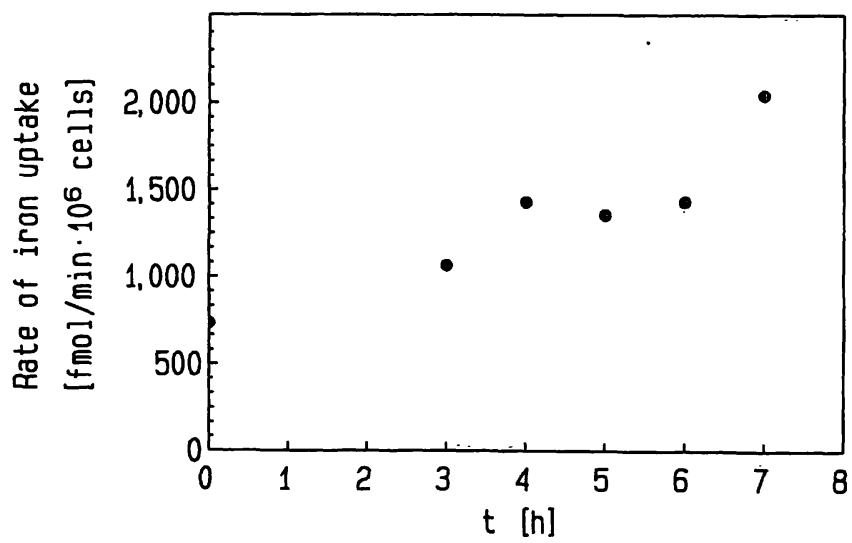

Fig. 7 Increase of the rate of iron uptake from Fe-citrate by lowiron dependent cells during incubation in $500 \mu \mathrm{mol} / \mathrm{l} \mathrm{Fe}$-citrate (high-iron medium).

The data are from two series of experiments.

inactivation of iron regulatory protein(s), leading to enhanced synthesis of ferritin, which then accumulates excess iron as a non-toxic storage from, protecting the cells from the deleterious effects of iron overload. At the same time, a concentration gradient of citrate, caused by initiation of the aconitase activity of the iron-regulatory protein leads to increased uptake of citrate, which may also exert protective effects against iron toxicity by forming complexes with low redox potential (27).

\section{Acknowledgements}

We are grateful to Dr. Ernst Müllner (Institute of Molecular Biology, University of Vienna) for performing the band-shift assays for iron-regulatory protein-activity. 


\section{References}

1. Kühn LC, Schulman HM, Ponka P. Iron-transferrin requirements and transferrin receptor expression in proliferating cells. In: Ponka P, Schulman HM, Woodworth RC, editors. Iron transport and storage. Boca Raton, Fla: CRC Press, 1990:149-91.

2. Thelander L, Reichard P. Reduction of ribonucleotides. Annu Rev Biochem 1979; 48:133-58.

3. Dautry-Varsat A, Ciechanover A, Lodish HF. $\mathrm{pH}$ and recycling of transferrin during receptor-mediated endocytosis. Proc Natl Acad Sci USA 1983; 80:2258-62.

4. Gutteridge JMC, Quinlan GJ. Antioxidant protection against organic and inorganic oxygen radicals by normal human plasma - the important primary role for iron-binding and ironoxidising proteins. Biochim Biophys Acta 1992; 1159:24854.

5. Harris DC, Rinehart AL, Hereld D, Schwartz RW, Burke FP, Salvador AP. Reduction potential of iron in transferrin. Biochim Biophys Acta 1985; 838:295-301.

6. Barnes D, Sato G. Serum-free cell culture: a unifying approach. Cell 1980; 22:649-55.

7. Neumannová V, Kovár J, Kriegerbecková K. Growth of human tumour cell lines in transferrin-free, low iron medium. In Vitro Cell Devel Biol 1995. In press.

8. White GP, Jacobs A. Iron uptake by Chang cells from transferrin, nitrilotriacetate and citrate complexes: the effects of ironloading and chelation with desferrioxamine. Biochim Biophys Acta 1978; 543:217-25.

9. Seligman PA, Kovar J, Schleicher RB, Gelfand EW. Transferrin-independent iron uptake supports lymphocyte-B growth. Blood 1991; 78:1526-31.

10. Kaplan J, Jordan I, Sturrock A. Regulation of the transferrinindependent iron transport system in cultured cells. J Biol Chem 1991; 266:2997-3004.

11. Hamazaki S, Glass J. Non-transferrin dependent Fe-59 uptake in phytohemagglutinin-stimulated human peripheral lymphocytes. Exp Hematol 1992; 20:436-41.

12. Inman RS, Wessling-Resnick M. Characterisation of transferrin-independent iron transport in K562 cells - unique properties provide evidence for multiple pathways of iron uptake. J Biol Chem 1993; 268:8521-8.

13. Oshiro S, Nakajima $H$, Markello T, Krasnewich D, Bernardini I, Gahl WA. Redox, transferrin-independent, and receptor-mediated endocytosis iron uptake systems in cultured human fibroblasts. J Biol Chem 1993; 268:21586-91.

14. Olakanmi O, Sokes J, Britigan BE. Acquisition of iron bounted to low molecular weight chelates by human monocyte-derived macrophages. J Immunol 1994; 153:2691-703.

15. Randell EW, Parkes JG, Olivieri NF, Templeton DM. Uptake of non-transferrin-bound iron by both reductive and nonreduc- tive processes is modulated by intracellular iron. J Biol Chem 1994; 279:16046-53.

16. Hodgson LL, Quail EA, Morgan EH. Receptor-independent uptake of transferrin-bound iron by reticulocytes. Arch Biochem Biophys 1994; 308:318-26.

17. Djeha A, Brock JH. Uptake and intracellular handling of iron from transferrin and iron chelates by mitogen stimulated mouse lymphocytes. Biochim Biophys Acta 1992; 1133:147-52.

18. Kovar J. Various cell lines grow in protein-free hybridoma medium. In Vitro Cell Devel Biol 1989; 25:395-6.

19. Kovar J, Franek F. Growth-stimulating effect of transferrin on a hybridoma cell line: relation to transferrin iron-transporting function. Exp Cell Res 1989; 182:358-69.

20. Aisen P, Listowsky I. Iron transport and storage proteins. Annu Rev Biochem 1980; 49:357-93.

21. Leibold EA, Munro HN. Cytoplasmic protein binds in vitro to a highly conserved sequence in the $5^{\prime}$ untranslated region of ferritin heavy- and light-subunit mRNAs. Proc Natl Acad Sci USA 1988; 85:2171-5.

22. Müllner EW, Neupert B, Kühn LC. A specific messenger RNA binding factor regulates the iron-dependent stability of cytoplasmic transferin receptor messenger RNA. Cell 1989: $58: 373-82$

23. Klausner RD, Rouault TA, Harford JB. Regulating the fate of messenger RNA - the control of cellular iron metabolism. Cell 1989; 72:19-28.

24. Aisen P, Leibman A, Zweier J. Stochiometric and site characteristics of the binding of iron to human transferrin. $\mathrm{J}$ Biol Chem 1978; 253:1930-7.

25. Jordan I, Kaplan J. The mammalian transferrin-independent iron transport system may involve a surface ferrireductase activity. Biochem J 1994; 302:875-9.

26. Gray NK, Quick S, Goossen B, Constable A, Hirling H, Kühn LC, Hentze MW. Recombinant iron-regulatory factor functions as an iron-responsive element-binding protein, a translational repressor and an aconitase. A functional assay for translational repression and direct demonstration of the iron switch-iron loading of irf. Eur J Biochem 1993; 218: 657-67.

27. Buettner GR. The pecking order of free radicals and antioxidants: lipid peroxidation, $\alpha$-tocopherol and ascorbate. Arch Biochem Biophys 1993; 300:535-43.

Univ.-Prov. Dr. Hans Goldenberg
Institut für Medizinische Chemie
Währingerstrasse 10
A-1090 Wien
Austria

Univ.-Prov. Dr. Hans Goldenberg Währingerstrasse 10

Austria 


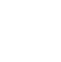

